\title{
Entrevista a CARMen GIL, realizada por Lourdes Sánchez Vera y Beatriz Sánchez Hita
}

\author{
Carmen Gil-Bonachera Martínez \\ poemitas@hotmail.com
}

\begin{abstract}
Pregunta: Con más de cien libros publicados y habiendo trabajado todos los géneros (novela, cuento en prosa y verso, poemas e incluso teatro - género muy poco habitual en la oferta editorial para los más jóvenes-), así como ejerciendo como traductora, su determinación en escribir para los más jóvenes parece clara; ¿qué la lleva a decidirse a escribir para niños?, y ¿por qué otorga un papel relevante a la producción de poesía y cuentos en verso?
\end{abstract}

Respuesta: Siempre me han encantado los niños y los libros. Así que conjugar mis dos pasiones fue algo natural.

Me gusta escribir para niños, porque se entregan sin reservas, valoran las cosas pequeñas que para los adultos carecen de importancia y se sorprenden con ellas. Los niños se mueven en un mundo mágico en el que todo es posible, en el que las hadas madrinas se reúnen en una nube para comer pizza margarita, una familia de fantasmas vive en el desván de tu casa o una princesa está hasta la coronilla de pasarse la vida esperando a su príncipe azul y decide meterse a caballera...

Siento un profundo respeto por mis lectores. Para escribir para niños no hay que convertirse en niño; pero sí entablar una relación de empatía con ellos, que ha de fluir espontáneamente, y que en ningún caso se puede forzar.

La poesía está presente en la vida del niño desde que nace. Con versos lo acunan, con frases rimadas aprende a comer o a localizar los dedos de sus manos. Más adelante, las adivinanzas, los trabalenguas, las canciones... forman parte de sus juegos.

Los niños disfrutan de la poesía sin prejuicios. ¡Les encanta la música de las palabras!

Como decía Carmen Bravo Villasante, en esta época utilitarista, la poesía se hace más necesaria que nunca. Y aporta, entre otras cosas, una nueva forma de mirar el mundo.

Pregunta: ¿Qué obras y autores situaría como sus referentes en el campo de la literatura infantil y juvenil?, ¿qué leía de niña o sigue leyendo Carmen Gil?

Respuesta: Creo que críticos y especialistas ya hablan bastante de literatura infantil y juvenil. Ha llegado la hora de dejar hablar a los lectores. Y, por lo que investigo y observo, sé que a los pequeños les sigue fascinando la narrativa políticamente incorrecta de Roaldh Dahl, la ternura de los libros de Juan Muñoz Martín, la literatura un poco gamberra de los libros de Greg, la magia de la saga de Harry Potter... Los adolescentes 
devoran todo lo que escribe Blue Jeans, les fascinan Laura Gallego, John Green, Suzanne Collins, Verónica Roth...

Cuando era pequeña leía prácticamente todo lo que caía en mis manos. Pero recuerdo con especial cariño las visitas mágicas a la librería las mañanas de domingo. ¡Cuánto me fascinaba aquel cordel, a modo de tendedero, lleno de pinzas de colores de las que colgaban cuentos troquelados! Eran los cuentos de Ferrándiz, que fueron mi primer contacto con la lectura: Nora locutora, El urbano Román, Mariuca la castañera, La guitarra embrujada de Currito el Cantaor... Bueno..., estos y los tebeos que leía en la sala infantil de la biblioteca, a la que iba casi a diario.

Pregunta: Sin duda, hoy nadie pondría en tela de juicio el destacado lugar que ocupa Carmen Gil entre los escritores de literatura infantil y juvenil en España, pero queríamos saber si en algún momento ha sentido que no se valoraba su trabajo o si siente o piensa que incluso en nuestros días a veces se entiende esta literatura como una producción menor.

Respuesta: Sí, claro que lo he sentido. La literatura infantil no es un destierro, sino una vocación. No estamos en ella porque no podamos escribir para adultos, sino porque no queremos. Esto es difícil de meter en la cabeza de algunos. Pero no me preocupa demasiado, la verdad. El reconocimiento está bien. Sin embargo, para mí, lo importante es tener la oportunidad de seguir publicando y llegar a los lectores. Y que ellos disfruten y se emocionen con mis textos. Cuando voy a un colegio y me esperan con los ojos brillantes de ilusión y un libro mío apretado contra el pecho; cuando una madre me dice que ha tenido que llevar a su hijo con fiebre porque se moría de ganas de conocerme; cuando los oigo reír a carcajadas con mis textos y recitar de memoria mis versos, sin que nadie los haya obligado aprendérselos...., toco la nube con la punta de los dedos. Y creedme, me importa muy poco si la literatura infantil se considera producción menor o no.

Pregunta: De entre su ingente producción, ¿hay alguna obra u obras cuya elaboración recuerde con especial cariño?, ¿y algún título que le costase concluir más de lo esperado?

Respuesta: Sin duda Un fantasma con asma, porque fue la primera y se ha convertido casi en una bandera. Y, por supuesto, los libros que están en proceso de edición. Hay dos de ellos muy "Carmen Gil", en los que cuento cosas que tenía muchas ganas de gritarle al mundo.

No recuerdo ningún libro que me costase terminar más de lo esperado. Sí que hubo una vez un original que le entregué a una editorial y me pidió bastantes cambios. Pero le dije que no y ya está. Ahora está en proceso de edición con otra.

Pregunta: Con varios los títulos que han sido traducidos a otros idiomas, ¿cómo vive el autor el proceso de traducción?, ¿qué miedos o recelos surgen?

Respuesta: Con una emoción enorme. Yo digo siempre que mis libros tienen alas. Es fascinante ver mis palabras en chino, en hebreo o en polaco. E imaginar cómo lo que 
pienso y escribo aquí, en un pueblo de nata con velos en el aire, dibuja más tarde sonrisas en tantos rincones del mundo.

Pregunta: De igual modo, ha traducido varios títulos al español como El pez que gritaba tiburón y otros títulos en la colección CU-CÚ GLUPS, ¿qué dificultades encuentra en esta práctica?

Respuesta: La verdad es que no son traducciones, sino adaptaciones, y eso da una enorme libertad. Tratándose de versos, es casi necesaria. Intento respetar el mensaje y la ilustración, y lo cuento a mi manera. Así no hay problemas de rima ni de ritmo.

Pregunta: Por otro lado, atendiendo a la importancia que la edición de álbumes ilustrados ha alcanzado en nuestros días, especialmente en lo que atañe a la producción para niños, quisiéramos preguntarle cómo enfoca un autor la ilustración de sus obras y cómo es el proceso, la relación con el ilustrador, si suele aportar ideas o bocetos..., y en qué medida considera que la recepción de la obra viene marcada por la imagen.

Respuesta: Soy muy respetuosa con la labor del ilustrador y no interfiero en ella jamás. Aunque es verdad que hay veces que me siento más en sintonía con los dibujos y otras menos, generalmente quedo muy contenta con el resultado final. Confío en las editoriales y son ellas las que velan porque haya armonía y el libro quede redondo. En una ocasión me ocurrió algo muy divertido. Una editorial de renombre me dio unas ilustraciones preciosas, de un ilustrador Premio Nacional, que se le habían quedado colgadas, porque el escritor no las había aceptado. Yo las barajé y a partir de ellas inventé una historia. Fue un reto, una especie de taller de literatura. Disfruté mucho.

La aprobación de un original viene tan marcada por las imágenes que este verano, precisamente, una editorial me rechazaba un texto que consideraba muy bien escrito y redondo, por, cito palabras textuales, "ser plenamente autosuficiente, estar concebido para ser comprendido y disfrutado desde lo verbal, por lo que se relegaría la ilustración a un papel secundario”. Fíjate si texto e ilustración deben formar un tándem.

Pregunta: En los últimos años ha podido apreciarse como parte del auge de la literatura infantil y juvenil se relaciona con el diseño por parte de algunas reconocidas editoriales de programas de lectura para el aula, ¿qué opina sobre estas prácticas?

Repuesta: Todo lo que fomente la lectura es bienvenido. Sin embargo, como maestra, no lo comparto. Mis chavales escogen los libros que les gustan y no tienen que hacer ningún tipo de trabajo tras la lectura. Para mí, el objetivo es que disfruten, que se aficionen, que lean por placer y terminen haciéndolo por necesidad.

Pregunta: Parte del aumento de lectores infantiles y juveniles tiene que ver con la labor de los docentes en el fomento de la lectura ¿cómo ve ese trabajo?, ¿detecta carencias con respecto al fomento de géneros no narrativos?

Respuesta: Estoy convencida de que en las escuelas se trabaja mucho y bien la animación de la lectura. De hecho, cuando recibí la medalla de oro se la dediqué a los maestros que, discretamente, dedican enormes esfuerzos a esta tarea. 
Es verdad que poesía y teatro son las cenicientas de la literatura infantil. ¿Qué porcentaje de libros de estos géneros hay en las bibliotecas escolares? Quizá se debe a la falta de preparación, al desconocimiento de la literatura infantil por parte de los docentes. Sin embargo, no es culpa de ellos. Considero inconcebible que la Literatura Infantil no sea una asignatura obligatoria para los futuros maestros de Infantil y Primaria.

Pregunta: A su entender ¿cuál debería ser el papel de la familia en el desarrollo lector de niños y jóvenes?

Respuesta: ¡Fundamental! Si los padres les cuentan cuentos a sus hijos cuando son pequeños, si hablan entre ellos de libros como de objetos placenteros, si hacen de la visita a la librería una fiesta, si se informan sobre libros infantiles de calidad preguntando a libreros documentados, si leen delante de sus hijos, si comparten con ellos sus lecturas, etc., etc., etc., habrá muchas más posibilidades de que esos niños se conviertan en futuros lectores.

\section{Nota de las editoras:}

Carmen Gil Bonachera es natural de La Línea de la Concepción (Cádiz). Su trabajo como maestra le llevó a escribir primero para sus alumnos y al descubrir que disfrutaban con sus producciones se animó a ampliar el grupo de sus destinatarios empezando a publicar sus creaciones.

Ha publicado más de cien libros de Literatura Infantil y aunque la mayor parte de su producción la ha dedicado a la poesía también tiene libros de teatro y de narrativa. Su gran pasión es jugar con las palabras y hacer magia con ellas para sorprender al lector.

Por su producción literaria ha obtenido premios y menciones tanto nacionales como internacionales y su obra ha sido traducida a múltiples idiomas, desde los más cercanos como el portugués, el francés o el inglés hasta otros tan exóticos como el taiwanés o el vietnamita.

Paralelo a su trabajo como escritora ha desarrollado una importante labor como animadora y son muchos los talleres para jóvenes lectores, docentes o padres en los que busca transmitir la magia de las palabras, intentando como ella misma dice "convencer por encantamiento". En esta faceta colabora con prestigiosas instituciones como el Instituto Cervantes o el Centro Andaluz de las Letras. Por la actividad desarrollada en el campo de la animación lectora posee la Medalla de Oro al Mérito en Educación en Andalucía 2011. 